\title{
ANALYSING THE SIMILARITIES BETWEEN OECD PRINCIPLES VERSUS EUROPEAN CORPORATE GOVERNANCE CODES - AN INTERNAL AUDIT PERSPECTIVE
}

\author{
Cristina Boța-Avram ${ }^{1}$ \\ Paula Ramona Răchişan ${ }^{2}$
}

\begin{abstract}
The aim of this paper is to realise a comprehensive analysis of European corporate governance codes, from the perspective of internal audit, in the manner it is provided in the OECD Principles of corporate governance. The research methodology used a classification of countries by legal regime and the determination of Russel and Rao Similarity Measure, aiming to obtain a global view over the similarity between the European corporate governance codes and the OECD Principles provisions, from internal audit's perspective. The findings suggest that countries from "Former socialists" group are less similar to OECD Principles, from internal audit perspective, while the countries from "French Civil" and "Scandinavian Civil" have a better similarity measure comparing to OECD Principles of corporate governance.
\end{abstract}

Keywords: similarities, OECD Principles, European corporate governance codes, internal audit.

JEL Codes: M21, M40, M42, M49

\section{Introduction}

The key role assigned to the audit function has become more and more significant, especially in the context of the latest evolutions of the international economic context, which emphasizes more and more the stringent necessity that internal audit to become more and more active, with a major contribution in the process of business administration (Allen, 2008; D'Silva \& Ridley, 2007; Paape et al, 2003; Puțan et al., 2012; Berinde, 2013). In the light of latest significant changes of international economic context, the governance bodies like executive management and board of directors have started to claim higher and higher expectations from the chief internal auditor and his department. Due to its strategic position, the internal audit function being located to the central point of interests for management, board of directors, shareholders and other stakeholders, it's now more and more important for internal audit to understand the adequate functioning of the corporate governance mechanisms, looking for a continuous enhancing of their activities and their skills, in order to obtain a global vision over the corporate governance system and its effectiveness (Allen, 2008; Leung, 2003; Berinde and Groşanu, 2013).

This paper is structured as follows. The next section discusses shortly the developments of internal audit in the context of corporate governance at European level. Next section describes the evolution and development of OECD Principles of Corporate Governance. It is followed by a section describing the research methodology used, defining also the data source and the population. Thereafter, an analysis of similarity of European corporate governance codes comparing to OECD Principles from internal audit's perspective is presented. Finally, the last section contains discussions and conclusions.

\footnotetext{
${ }^{1}$ Babeş-Bolyai University, Cluj-Napoca, Romania, e-mail: botaavram@gmail.com

${ }^{2}$ Babeş-Bolyai University, Cluj-Napoca, Romania, e-mail: ramona.rachisan@tbs.ubbcluj.ro
} 


\section{Internal audit in corporate governance - background literature}

The spectrum of various determinant factors for the latest economic international crisis was deeply analysed by scholarships from different perspectives. One of the causal factors considered was internal audit function and its responsibilities in enhancing the framework of corporate governance. Thus, internal auditors were criticised because their responsibilities in providing real adding value for the risk management process were not effectively achieved. Therefore, internal audit had been failed in providing the warning signals of ineffective corporate governance and weaknesses of risk management process. Such deficiencies and their impact on the latest economic evolution at global level were emphasized by the report issued by a group of lawmakers from United States of America, UK, France, Germany, and Switzerland (Senior Supervisors Group, 2008).

One thing is clear that developing tools for managing the potential risks that might affect an entity is not a responsibility of internal audit function. But, the major role that internal audit should play consists in delivering timely and well written reports to the governance bodies referring to the assessment of various types of risks, but also monitoring the effectiveness in the process of managing all these risks. (Leech, 2008; Boța-Avram, 2011).

In terms of corporate governance, another element that will influence further evolution of internal audit function will be the nature of its relationship with the audit committee (Mat Zain \& Subramaniam, 2007; Sarens \& DeBeelde, 2006; Mat Zain et al., 2006; Krishnan, 2005; Gramlin et al, 2004; Goodwin, 2003), being promoted the idea that if the audit committee will be perceived by the internal auditor department as a independent governance body where various business aspects are discussed and solved, than it is more likely to have a good corporate governance framework.

Considering the latest developments of corporate governance issues, the importance and attention paid to the internal audit function is more and more significant. In the context of growing expectations of management, board of directors and other stakeholders, internal auditor should become more effective and more strongly involved in providing assurance to governance bodies in managing business successfully (Allen, 2008).

Also, another next perspective in developing the role and responsibilities of internal audit in the context of corporate governance will be given by the necessity to approach internal audit function as one of the three major pillars of audit function. Porter (2009) looking for a more clear distinction between corporate accountability and corporate governance, has examined the role of the tripartite audit function (with all its three pillars: internal audit, external audit and audit committee), assigning to the internal audit department the position of "internal company watchdog".

Therefore, internal audit, through its practices and considering the main principles of corporate governance that should be comply with, must make the proof of having the necessary skills and abilities to understand all the key-elements of the corporate governance framework, in order to be able to properly identify the significant areas of the business, so that internal audit really become a "value-added provider" and not just a "cost-centre".

\section{The internal audit in European corporate governance}

In the context of European corporate governance, a special attention was given to the internal audit, mainly after the recommendation of European Commission of 15 February 2005 (EC, 2005), which outlines the necessity that each listed company should have an internal audit function, under the supervision of the Audit Committee, which has to monitor the effectiveness of internal audit function, in order to ensure the proper functioning on all companies' transactions, on internal reporting and control systems.

The attention given to the internal audit function at European level was also strongly stimulated by the position paper published by the European Confederations of Institutes of Internal Audit (ECIIA, 2005). European Confederation of Institutes of Internal Audit (ECIIA) is a confederation of over 30 national associations of internal auditing located in countries within the 
wider geographic area of Europe and the Mediterranean basin representing a membership base of over 40,000 professionals. Its main purpose is to promote sound corporate governance, risk management and the internal auditing profession. The main roles assigned to the internal audit by ECIIA (2005) paper are referring to assurance and consulting. The assurance delivered by internal audit is represented by the support given to the management by "providing objective assurance on the effectiveness of the process for the achieving good governance, risk management and internal control", On the other hand, such activities performed by internal audit will also "provide consulting services, facilitating and advising on improvements in these areas".

At European level each country member of European Union has established a national corporate governance code, intended mainly for the listed companies. Most of the European governance codes are based on the applying of the „,comply or explain” principle, given to the European Directive 2006/46/CE which recommends the applying of the corporate governance principles, while a specific requirement for listed companies is to issue the report on corporate governance where the conformity to be certified or the non-conformity with national corporate governance code to be explained. Even if the main objectives of corporate governance are already well known and largely incorporated in European corporate governance codes, an analysis over the way the internal audit's role and responsibilities are developed within those European governance codes would be interesting and could stimulate further debates over the enhancing of the internal audit's contribution to a most effective corporate governance.

\section{OECD principles of corporate governance}

The Organisation for Economic Cooperation and Development (OECD) has as main objective the promoting of the policies that will enhance the economic and social well-being of people around the world. The OECD aims to provide a forum in which governments may work together in looking for solutions to common problems that influence the economic, social and environmental aspects of citizen's life. OECD is one of the main professional bodies preoccupied in the development of corporate governance standards. First edition of OECD Principles of Corporate Governance was adopted in 1999, and since then it became one of the reference framework for supporting reforms in terms of corporate governance. The main idea in developing these principles was that there is no single model of corporate governance general accepted in all countries and organisations, but OECD Principles identified the main standards that can be applied in a variety of economic environments, legal and political, aiming to support governments in their efforts to assess and improve the legal, institutional and regulatory framework for corporate governance system of their countries.

The conceptual framework of corporate governance varies from country to country, depending on the degree of economic development of each country. For these reasons, the application of OECD principles cannot be imposed as a mandatory requirement, but they should be considered rather as a set of recommendations designed to help every country in pushing forward economic life of their organizations, but not disturb respecting traditions and specific market conditions characteristic of each country. Since 1999, these principles have been widely adopted as a conceptual frame of reference for best practices in corporate governance, while serving as a starting point in developing a large number of corporate governance codes. This guidance provided by the OECD Principles is offered both members OECD countries and non-members of OECD countries, being at the same time, a basis for an extensive program of cooperation between OECD countries and non-OECD countries, aiming to ensure international financial stability, providing support for the World Bank in its work to improve corporate governance in emerging markets. After the publication of OECD Principles in 1999, there have been followed a lot of bankruptcies of large corporations, which generated lower investor confidence in financial markets, and in the organizational ability of management. This is one of the reasons that led, in 2002 at OECD meeting, 
to the proposal to proceed to the OECD Principles revision, trying to adapt them to the new conditions that characterize global financial and economic lives.

The result was materialised by the approval, on 22 April 2004, of a revised OECD Principles of Corporate Governance, adding a number of new recommendations and modifying existing others. The revised text is the product of a consultative process among OECD members, representatives from OECD member countries and non-OECD countries, including professional and business organizations, civil society organizations and professional bodies governing international standards in various fields.

This review of OECD Principles aiming to provide a set of standards and best practices on corporate governance without assigning them a mandatory character, while they can be adapted to the particular conditions of each region or country. OECD encourages continuous dialogue and exchange of experiences between member countries and non-OECD countries, providing the opportunity to discuss various topics through a forum. In order to keep always up to date on the conditions that characterize the various economies of the world, because economic conditions are constantly changing, the OECD has established certain departments that should closely monitor all developments in corporate governance, identifying trends and seeking solutions adapted to the economic and social challenges. Also, the OECD conducted a study entitled "Study on corporate governance developments in OECD countries" (OECD, 2002) aiming to identify the experiences gained from the application of these principles. All these consultations characterized by transparency were materialised in January 2004, when it was posted on the Internet a draft revised version of OECD Principles for public comment.

The main key elements of OECD Principles of Corporate Governance (OECD, 2004) include at least:

- Providing a basis for an effective corporate governance framework: The corporate governance framework should promote transparent and efficient markets, be consistent with the rule of law and make a clear division of responsibilities among different supervisory authorities, regulatory and application;

- The shareholders' rights and managerial ownership: according to which corporate governance framework should protect and facilitate the proper exercise of shareholders' rights;

- Equitable treatment of shareholders: corporate governance framework should ensure the equitable treatment of all shareholders. All shareholders should be able to get an early recovery of their rights.

- Role of stakeholders in corporate governance: corporate governance framework should recognize the rights of the various parties involved recognized by law or by mutual agreement, encouraging active cooperation between economic entities and stakeholders to create assets, jobs and sustainability entities with a good financial standing;

- Information and transparency: corporate governance framework should ensure the performance of relevant and accurate information on all important aspects of the organization, including the financial situation, performance, ownership and management organization;

- Board responsibilities: corporate governance framework should ensure the strategic direction of the organization, effective monitoring of management by the board of directors and real accountability of the board to the organization and its shareholders.

As a response to the new challenges of the present, the application of OECD principles was reviewed in at least the following five main areas (Witherell, 2004):

1. The ensuring the sound corporate governance framework, including effective regulatory and enforcement mechanisms

2. The improving opportunities for shareholders to effectively exercise their ownership

3. The increasing of transparency, paying special attention to conflicts of interest,

4. The providing protection for those persons who transmit warnings;

5. Increasing responsibilities of the Board. 


\section{Research methodology}

The main purpose of this paper was to develop a content analysis of the European Corporate Governance Codes, from the internal audit perspective, by measuring the similarity with the main provisions concerning the internal audit within OECD Principles of Corporate Governance. Also, it was used the classification of legal regimes (La Porta et al., 1998; Cicon et al., 2012) in order to identify the potential influence of legal regime over the similarity with OECD Principles, which is disclosed in Table 1. Thus, the criteria for analysing the provisions concerning the internal audit, from OECD's perspective are reported in Table 2. For developing this analysis, all 27 European corporate governance codes were analysed according to the criteria established. The similarity of European Corporate Governance codes was computed by using Russel and Rao similarity measure, trying to find some answers to the next research questions:

- Research question 1: It is well accepted and recognised the role of internal audit function in the context of European corporate governance, taking in account the recommendations of OECD Principles?

- Research question 2: Referring to European corporate governance codes and OECD Principles, it is there a good similarity level concerning the role of internal audit in terms of corporate governance?

\section{Countries classification by legal regime}

\begin{tabular}{lll}
\hline & Legal Regime & \multicolumn{2}{c}{ Countries included } \\
\hline Common Law & 1. & UK \\
& 2. & Ireland \\
\hline German Civil & 1. & Austria \\
& 2. & Germany \\
\hline French Civil & 1. & Belgium \\
& 2. & France \\
& 3. & Greece \\
& 4. & Italy \\
& 5. & Luxembourg \\
& 6. & Netherlands \\
& 7. & Portugal \\
& 8. & Spain \\
& 9. & Cyprus \\
\hline Former Socialists & 10. & Malta \\
\hline & 1. & Denmark \\
& 2. & Finland \\
& 3. & Sweden \\
\hline & 1. & Bulgaria \\
& 2. & Czech Republic \\
& 3. & Estonia \\
& 4. & Hungary \\
& 5. & Latvia \\
& 6. & Lithuania \\
& 7. & Poland \\
& 8. & Romania \\
& 9. & Slovakia \\
& 10. & Slovenia \\
\hline
\end{tabular}

Russel and Rao binary similarity coefficient determines a similarity distance that relates to the total number of times, when specific conditions compared to the referenced framework are 
achieved. This coefficient of similarity seems to be a reasonable choice for many studies in the scholarship literature, and will take the value 0 , when it is a full dissimilarity between two compared framework and will take the value 1 when is complete similarity. The values between 0 and 1 show the degree of similarity between two compared frameworks.

Table no. 2.

\section{Provisions regarding internal audit - OECD's perspective}

\section{Internal audit's position within the company}

Internal audit system is directly reporting to the board or to an independent committee.

Internal auditor should have direct access to the board

Non-executive board members should have access to the internal auditor.

\section{Internal audit's role and responsibilities}

* The oversight of internal control systems covering financial reporting

* The monitor of the using of corporate assets

* The oversight of the guard against abusive related party transactions

* an appropriate oversight of the integrity of the essential reporting and monitoring systems

\section{Relationship between internal audit and audit committee}

Internal audit is monitored by the audit committee

Internal audit reports are available to the audit committee

Source: author's projection

\section{Data analysis}

For developing this study it was accessed the website of European Corporate Governance Institute (www.ecgi.codes) where all European corporate governance codes are available. The analysis of the latest revisions of European corporate governance codes reveals the attention given by UE member states to this problematic area of corporate governance (Fig. no.1).

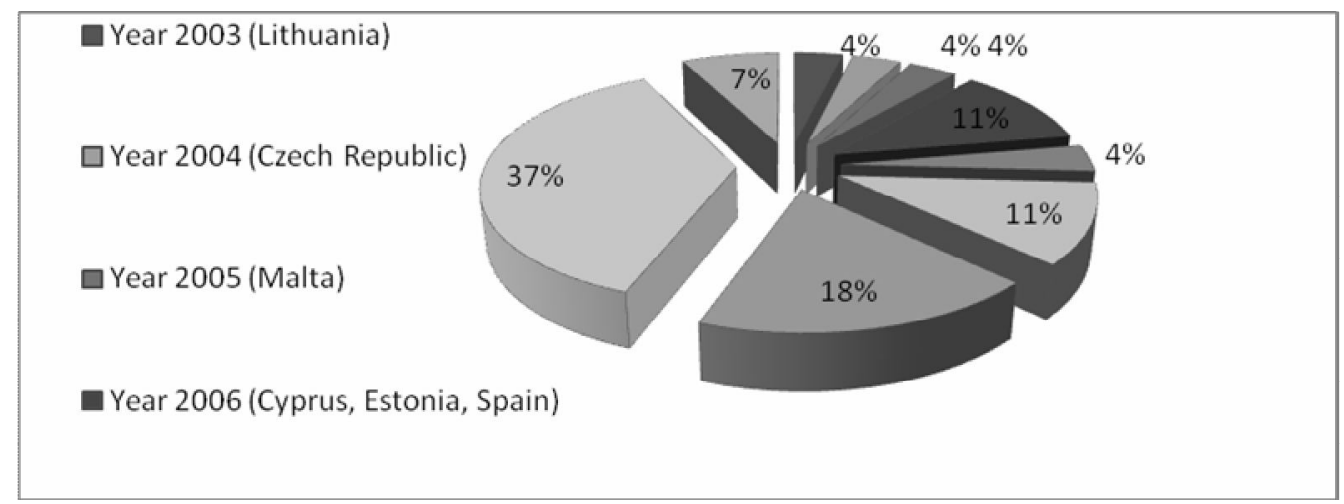

Figure no. 1. - Latest revision of European corporate governance codes

The results of similarity analysis between European Corporate governance Codes and OECD Principles, from internal audit's perspective are next reported (Table no.3, 4, 5, 6 and 7). 
Similarity in Common Law countries

\begin{tabular}{ccc}
\hline Common Law & OECD vs Ireland & OECD vs UK \\
\hline & Sij & Sij \\
\hline internal audit's position within the company & 0,333 & 0,333 \\
\hline internal audit's role and responsibilities & 0,250 & 0,000 \\
\hline relationship between internal audit and audit committee & 0,000 & 1,000 \\
\hline
\end{tabular}

Source: author's projection

Table no. 4.

Similarity in German Civil countries

\begin{tabular}{crr}
\hline German Civil & OECD vs Austria & \multicolumn{1}{c}{ OECD vs Germany } \\
\hline internal audit's position within the company & Sij & Sij \\
\hline internal audit's role and responsibilities & 0,333 & 0,000 \\
\hline relationship between internal audit and audit committee & 0,000 & 0,000 \\
\hline
\end{tabular}

Source: author's projection

Table no. 5.

Similarity in Scandinavian Civil countries

\begin{tabular}{cccc}
\hline Scandinavian Civil & $\begin{array}{c}\text { OECD vs } \\
\text { Denmark }\end{array}$ & $\begin{array}{c}\text { OECD vs } \\
\text { Finland }\end{array}$ & $\begin{array}{c}\text { OECD vs } \\
\text { Sweden }\end{array}$ \\
\hline internal audit's position within the company & 1,000 & Sij & Sij \\
\hline internal audit's role and responsibilities & 0,500 & 1,000 & 0,000 \\
\hline relationship between internal audit and audit committee & 1,000 & 0,500 & 0,000 \\
\hline
\end{tabular}

Source: author's projection 
Similarity in French Civil countries

Table no.6.

\begin{tabular}{lcccccccccc}
\hline \multicolumn{1}{c}{ French Civil } & $\begin{array}{c}\text { OECD } \\
\text { vs } \\
\text { Belgium }\end{array}$ & $\begin{array}{c}\text { OECD } \\
\text { Cyprus }\end{array}$ & $\begin{array}{c}\text { OECD } \\
\text { France }\end{array}$ & $\begin{array}{c}\text { OECD } \\
\text { vs } \\
\text { Greece }\end{array}$ & $\begin{array}{c}\text { OECD } \\
\text { vs } \\
\text { Italy }\end{array}$ & $\begin{array}{c}\text { OECD } \\
\text { vs } \\
\text { Luxembourg }\end{array}$ & $\begin{array}{c}\text { OECD } \\
\text { vs } \\
\text { Malta }\end{array}$ & $\begin{array}{c}\text { OECD } \\
\text { vs } \\
\text { Portugal }\end{array}$ & $\begin{array}{c}\text { OECD } \\
\text { vs } \\
\text { Netherlands }\end{array}$ & $\begin{array}{c}\text { OECD } \\
\text { vs } \\
\text { Spain }\end{array}$ \\
\hline & $\mathrm{Sij}$ & $\mathrm{Sij}$ & $\mathrm{Sij}$ & $\mathrm{Sij}$ & $\mathrm{Sij}$ & $\mathrm{Sij}$ & $\mathrm{Sij}$ & $\mathrm{Sij}$ & $\mathrm{Sij}$ & $\mathrm{Sij}$ \\
\hline $\begin{array}{l}\text { internal audit's position } \\
\text { within the company }\end{array}$ & 1,000 & 1,000 & 0,000 & 1,000 & 0,333 & 0,333 & 0,000 & 1,000 & 1,000 & 1,000 \\
\hline $\begin{array}{l}\text { internal audit's role and } \\
\text { responsibilities }\end{array}$ & 0,250 & 0,000 & 0,000 & 0,000 & 0,250 & 0,000 & 0,000 & 0,250 & 0,000 & 0,500 \\
\hline $\begin{array}{l}\text { relationship between internal } \\
\text { audit and audit committee }\end{array}$ & 1,000 & 0,000 & 0,000 & 1,000 & 1,000 & 1,000 & 1,000 & 1,000 & 1,000 & 1,000 \\
\hline
\end{tabular}

Source: author's projection

Table no. 7.

Similarity in Former Socialists countries

\begin{tabular}{|c|c|c|c|c|c|c|c|c|c|c|}
\hline $\begin{array}{l}\text { Former } \\
\text { Socialists } \\
\text { countries }\end{array}$ & $\begin{array}{c}\text { OECD } \\
\text { vs } \\
\text { Bulgaria }\end{array}$ & $\begin{array}{c}\text { OECD } \\
\text { vs } \\
\text { Czech Republic }\end{array}$ & $\begin{array}{c}\text { OECD } \\
\text { vs } \\
\text { Estonia }\end{array}$ & $\begin{array}{c}\text { OECD } \\
\text { vs } \\
\text { Hungary }\end{array}$ & $\begin{array}{l}\text { OECD } \\
\text { vs } \\
\text { Latvia }\end{array}$ & $\begin{array}{c}\text { OECD } \\
\text { vs } \\
\text { Lithuania }\end{array}$ & $\begin{array}{l}\text { OECD } \\
\text { vs } \\
\text { Poland }\end{array}$ & $\begin{array}{c}\text { OECD } \\
\text { vs } \\
\text { Romania }\end{array}$ & $\begin{array}{c}\text { OECD } \\
\text { vs } \\
\text { Slovakia }\end{array}$ & $\begin{array}{c}\text { OECD } \\
\text { vs } \\
\text { Slovenia }\end{array}$ \\
\hline & Sij & Sij & Sij & Sij & Sij & Sij & Sij & Sij & Sij & Sij \\
\hline $\begin{array}{l}\text { Internal audit's } \\
\text { position within } \\
\text { the company }\end{array}$ & 0,000 & 1,000 & 0,000 & 1,000 & 0,000 & 0,000 & 0,000 & 0,000 & 1,000 & 1,000 \\
\hline $\begin{array}{l}\text { internal audit's } \\
\text { role and } \\
\text { responsibilities }\end{array}$ & 0,000 & 0,000 & 0,000 & 0,500 & 0,000 & 0,000 & 0,000 & 0,000 & 1,000 & 0,500 \\
\hline $\begin{array}{l}\text { relationship } \\
\text { between } \\
\text { internal audit } \\
\text { and audit } \\
\text { committee }\end{array}$ & 0,000 & 1,000 & 0,000 & 1,000 & 0,000 & 0,000 & 0,000 & 0,000 & 1,000 & 1,000 \\
\hline
\end{tabular}


Analysing the results, it can be observe that countries from "Former socialists" are less similar to OECD Principles, from internal audit perspective, only Slovakia, Slovenia and Hungary seems to have a good level of similarity with OECD Principles. Analysing the countries from "French Civil" and "Scandinavian Civil" groups, they seems to have a better measure of similarity measure comparing to OECD Principles of corporate governance, even if in these samples are few countries which are less or not at all (like France or Sweden) similar to criteria analysed.

\section{Conclusions}

If more than half of the UE members states are including in their CG code $a$ recommendation for the implementation of internal audit function, still there are too few countries (only 9 of 27 UE members states) that explicitly provide sufficient details about the position that internal audit should have within the company in order to ensure its (so much required) independence. Analysing how the responsibilities and the role of internal audit are defined explicitly within each national corporate governance framework, it can be easily noticed the small number (only 10 of 27 of the countries who have actually outlined the main tasks that internal audit should play in terms of corporate governance.

The aspects referring to the relationship between internal audit and audit committee seem to be much more in the attention of European governance codes. A potential explanation could be the bigger attention paid for defining the audit committee's responsibilities much clearer in the latest versions of governance codes, which actually highlights the relationship that audit committee should have with internal audit in terms of corporate governance.

The findings of the analysis developed over European governance codes, from internal audit's perspective, allowed us to observe the non-similarity in the recommendations referring to internal audit in the context of corporate governance, comparing to OECD Principles of Corporate Governance.

\section{Acknowledgements}

A previous version of this paper was presented as working paper within the "Third session of researchers scholars" within the project "Performance and excellence in postdoctoral research in economic sciences in Romania", Contract no. POSDRU/89/1.5/S/59184, project co-financed from European Social Fund through Sectoral Operational Programme Human Resources Development 2007-2013. This paper was supported from the European Social Fund through Sectorial Operational Programme Human Resources Development 2007-2013, research project POSDRU/89/1.5/S/59184 'Performance and excellence in postdoctoral research within the field of economic sciences in Romania', BabeşBolyai University, Cluj-Napoca being a partner within the project.

\section{References}

1. Allen, S., 2008. The value of internal audit in corporate governance, The Corporate Board, November/December 2008, 1-5.

2. Puțan, A., Topor, D.I., Gheorghian, M., 2012. Cognitive meanings of management control in estimating the degree for achieving the strategy, Annales Universitatis Apulensis Series Oeconomica, 14 (1), 81-87.

3. Berinde, S., Groşanu, A., 2013. The efficiency of foreign investments in the financing of audited entities, Annals of Faculty of Economics, 1 (1), 1289-1299.

4. Berinde, S. R., 2013. Forecasting the structure of the Romanian audit market, Studia Universitatis Babes Bolyai-Negotia, 3, 95-108.

5. Boța-Avram C., 2011. Some arguments that justify the audit's trinity's approach in the context of corporate governance, Studies in Business and Economics, 6 (1), 5-18. 
6. Cicon, J. E., Ferris, S. P., Kammel, A. J. and Noronha, G., 2012. European Corporate Governance: a Thematic Analysis of National Codes of Governance. European Financial Management, Vol.18, 620-648.

7. D'Silva, K. \& Ridley, J., 2007. Internal auditing's international contribution to governance, International Journal of Business Governance and Ethics, Vol.3, No.2, 113-126

8. ECIIA, 2005. Position Paper on Internal Auditing in Europe, European Confederation of Institutes of Internal Auditing, Brussels, Belgium.

9. European Commission, 2005. Commission recommendation of 15 February 2005 on the role of non-executive or supervisory directors of listed companies and on the committees of the (supervisory) board, 2005/162/EC, published in the Official Journal of the European Union L52/51 from 25.02.2005.

10. Goodwin, J., 2003. The Relationship between the Audit Committee and the Internal Audit Function: Evidence from Australia and New Zealand, International Journal of Auditing, Vol.7, 263-278.

11. Gramling, A. A., \& Maletta, M. J.\& Schneider, A. \& Church, B. K., 2004. The Role of the Internal Audit Function in Corporate Governance: A Synthesis of the Extant Internal Auditing Literature and Directions for Future Research, Journal of Accounting Literature, vol. 23, 194-244.

12. Krishnan, J., 2005. Audit Committee Quality and Internal Control: An Empirical Analysis, The Accounting Review, Vol.80, 649-675.

13. La Porta R., Lopez-de- Silanes F., Shleifer A., Vishny R., 1998. Law and Finance, Journal of Political Economy, Vol.106, No.6, 1113-1155.

14. Leech, T., 2008. The Global Economic Crisis: could Internal Audit have helped prevent it?, accessible on-line at http://www.accaglobal.com/pubs/economy/analysis/acca/ internal/economy_090309_3.pdf.

15. Leung, P., 2003. The role of internal audit in corporate governance and management in Australia, Research Project sponsored by IIA Research Foundation, IIA Australia and RMIT University, accessible on-line at www.theiia.org.

16. Mat Zain, M. \& Subramaniam, N.\& Stewaer, J., 2006. Internal Auditors' Assessment of their contribution to financial statement audits:the relation wih audit committes and internal audit function characteristics, International Journal of Auditing, Vol.10, 1-18.

17. Mat Zain, M. \& Subramaniam, N., 2007. Internal auditors perceptions on audit committes interactions: a qualitative study in Malaysian public corporation, Corporate Governance: an international review, Vol.15 No.5, 894-908.

18. Paape, L.\& Scheffe, J. \& Snoep, P., 2003. The relationship between the internal audit function and corporate governance in the EU - a survey, International Journal of Auditing, Vol.7, 247-262.

19. Porter, B.A., 2009. The audit trinity: the key to securing corporate accountability, Managerial Auditing Journal, Vol.24, No.2, 156-182.

20. Sarens, G. \& De Beelde, I., 2006. Interaction between internal auditors and the audit committee: an analysis of expectations and perceptions, Working paper, Universiteit Gent, Faculteit Economie en Bedrijfskunde.

21. Witherell B., 2004. The revised OECD principles of corporate governance: A management roadmap for healthy, well-governed companies, CFO Strategies: Corporate Accountability Forum 2004, Monaco, May 17, accesible on-line la http://www.oecd.org/dataoecd/63/56/32034047.pdf 